\title{
Varietal evaluation of Colocasia var. Muktakeshi under climatic condition of Tripura
}

\author{
SUBHRA SHIL AND DIPAK NATH* \\ Krishi Vigyan Kendra, DIVYODAYA (WEST TRIPURA) INDIA
}

\section{ARITCLE INFO}

Received : 18.03 .2015

Accepted : 28.03 .2015

\section{KEY WORDS :}

Colocasia, Varietal evaluation, Tripura

*Corresponding author:

Email:spd020@yahoo.co.in

\begin{abstract}
The experiment was conducted in a village of Gourangatilla, Khowai district of Tripura with full technical support and investigation of Krishi Vigyan Kendra scientists during 2013-14. The main objective of the experiment was to evaluate the performance of this high yielding variety of colocasia in comparison with local variety. It has been reported from the investigation that the variety Muktakeshi is better than the local variety in terms of yield, pest and disease per centage, eating quality with good size and shape. In case of var. Muktakeshi a highest yield of $140 \mathrm{q} / \mathrm{ha}$ and an average yield of $129 \mathrm{q} / \mathrm{ha}$ has been recorded while in case of local check average yield $100 \mathrm{q} /$ ha was observed.
\end{abstract}

How to view point the article : Shil, Subhra and Nath, Dipak (2015). Varietal evaluation of Colocasia var. Muktakeshi under climatic condition of Tripura. Internat. J. Plant Protec., 8(1) : 214-215. 